\title{
El Niño - related precipitation variability in Perú
}

\author{
P. $\operatorname{Lagos}^{1}$, Y. Silva ${ }^{1}$, E. Nickl ${ }^{2}$, and K. Mosquera ${ }^{1}$ \\ ${ }^{1}$ Instituto Geofísico del Perú, Lima, Perú \\ ${ }^{2}$ Department of Geography, University of Delaware, Delaware, USA
}

Received: 15 July 2007 - Revised: 19 November 2007 - Accepted: 19 November 2007 - Published: 10 April 2008

\begin{abstract}
The relationship between monthly mean sea surface temperature (SST) anomalies in the commonly used El Niño regions and precipitation for 44 stations in Perú is documented for 1950-2002. Linear lag correlation analysis is employed to establish the potential for statistical precipitation forecasts from SSTs. Useful monthly mean precipitation anomaly forecasts are possible for several locations and calendar months if SST anomalies in El Niño 1+2, Niño 3.4, and Niño 4 regions are available. Prediction of SST anomalies in El Niño regions is routinely available from Climate Prediction Center, NOAA, with reasonable skill in the El Niño 3.4 region, but the prediction in El Niño 1+2 region is less reliable. The feasibility of using predicted SST anomalies in the El Niño 3.4 region to predict SST anomalies in El Niño 1+2 region is discussed.
\end{abstract}

\section{Introduction}

El Niño in Peru is characterized by above normal sea surface temperatures (SSTs) along the coast and heavy precipitation in the northern coastal desert.

The warming and rains typically begin just after Christmas, hence the name El Niño or "the boy." Originally the term El Niño was used by sailors in the Paita area $\left(5^{\circ} \mathrm{S}\right)$ to describe a narrow current of warm surface water that moves south from Ecuador beginning at this time in most years and lasting several months (Carrillo, 1892). Studies of the ocean and weather conditions during the 1960s emphasized the anomalous warm years, and referred to those episodes as El Niños. Bjerknes $(1966,1969)$ documented coherent warm equatorial SST anomalies from the dateline to the Ecuador coast, and related this feature to both the warming at the

Correspondence to: $\mathrm{P}$. Lagos

(plagos@geo.igp.gob.pe)
Peru coast and to planetary-scale changes in the tropical atmosphere, the "Southern Oscillation".

In subsequent years, the term "El Niño" has been used in the literature to describe basin-scale equatorial Pacific warmings, and this has blurred the distinction with the coastal phenomenon, which while related to does not exhibit a oneto-one correspondence with the basin-scale SST variability (Rasmusson and Carpenter, 1982; Deser and Wallace, 1987; Trenberth and Stepaniak, 2001). This usage has lead to confusion and contradictions in the use of the term "El Niño" (Aceituno, 1992). In 1983 a Scientific Committee for Ocean Research (SCOR) working group 55 defined El Niño as "El Niño is the appearance of anomalously warm water along the coast of Ecuador and Perú as far south as Lima $\left(12^{\circ} \mathrm{S}\right)$. This means a normalized sea surface temperature (SST) anomaly exceeding one standard deviation for at least four (4) consecutive months. This normalized SST anomaly should occur at least at three (3) of five (5) Peruvian coastal stations", a definition that was equivalent to that used by Peruvian researchers, but it was not accepted by the international scientific community. Trenberth (1977) has explored possible definitions of El Niño and concluded that the definition is still evolving and alternative criteria might be used.

SST anomalies in the region $5^{\circ} \mathrm{N}$ to $5^{\circ} \mathrm{S}, 170-120^{\circ} \mathrm{W}$ (Fig. 1), referred to as "Niño 3.4", relate well to changes in the Northern Hemisphere extratropical winter circulation, and are also predictable to a useful degree by mechanistic and statistical models. For these reasons, NOAA's NWS Climate Services Division has adopted an operational definition for El Niño for monitoring and prediction purposes which is based on Niño 3.4 SST anomalies (3-month average SST anomaly $>=0.5 \mathrm{C}$ with respect to 1971-2000). The definition is at http://www.noaanews.noaa.gov/stories2005/s2394.htm.

When the area of interest is the South American Pacific coast, the NOAA definition differs from the local concept of El Niño which is equivalent to the SCOR definition. Also when the SST anomaly in the El Niño 3.4 region meets the

Published by Copernicus Publications on behalf of the European Geosciences Union. 


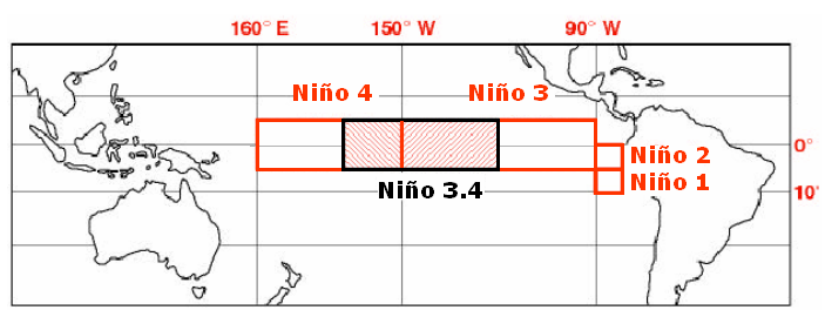

Fig. 1. Location of El Niño regions.

NOAA's El Niño criterion, the SST anomaly in the El Niño $1+2$ region may be smaller in amplitude, and hence an announcement of an El Niño event based on the NOAA definition leads to confusion among the Peruvian public, such as in the year 2003 and 2006. In this study, SST variations in El Niño 3.4 and El Niño 1+2 regions will be distinguished. In addition, numerous studies have examined the efficacy of El Niño/Southern Oscillation (ENSO)-related SST anomalies in various parts of the central and western equatorial Pacific to forcing atmospheric teleconnections (for example, Barsugli and Sardeshmukh 2002), but fewer studies have documented the relative importance of coastal- and basin-wide SST anomalies in forcing precipitation over Peru (Deser and Wallace, 1987; Nickl, 2007). Finally the present study documents the ENSO and El Niño signatures in Peru in greater geographic detail than in previous studies.

In Perú, precipitation occurs along the northern coast during El Niños, in the Andes and the Amazon in all years, and significant precipitation does not occur along the central and southern coast. The beginning and end of the precipitation seasons varies slightly from one region, and will be discussed in Sect. 4. The onset and intensity of precipitation varies from year to year, and in some years the variability can take the form of an extreme event, such as heavy or deficit of precipitation, which evolves into a natural disaster. Extreme precipitation events in the Andes have been associated by local investigators and, particularly by the local media, with El Niño events, despite the fact that the linkage between these climate events and El Niño has not been established.

Many studies have documented the variability of precipitations in different zones of South America and their relation with the basin-scale El Niño (Aceituno, 1988, 1989; Diaz et al., 1998; Grimm et al., 2000, 2002; Montecinos et al., 2000; Pisciottano et al., 1994). One of the most studied regions is the Amazon (Liebmann and Marengo, 2001; Marengo et al., 2001), but few have been made for the Andes (Vuille, et al., 2000; Villacis, 2001). The work of Ropelewski and Halpert $(1987,1989)$ related precipitation over broad regions of South America to ENSO.

In this paper the relationship between Perú precipitation and Perú-coast and basin-wide SST anomalies for 19502002 is characterized with linear lag correlation coefficients. The goal is to establish the potential for statistical precip- itation forecasts based on SST anomalies in the Niño 1+2 and 3.4 regions. The following sections describe the data, methodology, annual cycle and interannual variability, and the development of the forecast model.

\section{Data}

Monthly precipitations totals for 44 stations and the years 1950 to 2002 were selected for the study. Twenty-three of the stations are located at airports and belong to the Peruvian Corporation of Civil Aviation (CORPAC), and the data for the other 21 stations were compiled by the IGP from different sources. Precipitation anomalies are calculated with respect to 1961-1990. Table 1 lists the stations employed in the study.

Monthly values of the El Niño 1+2, Niño 3, Niño 3.4, and Niño 4 SST indices were obtained from the NOAA Climate Prediction Center WWW site and are derived from the NOAA optimal interpolation SST dataset (Reynolds and Smith, 1994). Anomalies are with respect to a $1961-90$ climatology.

\section{Methodology}

Pearson linear lag correlation analysis is employed to relate precipitation to SST indices for the El Niño 1+2, Niño 3, Niño 3,4 and Niño 4 regions. Two-dimensional correlation and scatter plots are also constructed to illustrate the relationship between El Niño 1+2 and Niño 3.4 indices.

\section{Annual cycle}

A knowledge of the annual cycle of precipitation over the Peruvian region is necessary for understanding the interannual variability, which is the focus of this study. Precipitation in the Andes begins in September and ends in May, with maximum values in the months of January-March, rapid diminution in April, and slight variations from station to station. In the extreme northern coast, seasonal precipitation begins during El Niños around November and ends around March. In the remainder of the coastal regions precipitation does not occur, and in the Amazon basin precipitation begins around August and ends around June.

The annual cycle of precipitation in the Peruvian Andes is associated with the seasonal displacement of the South Pacific and South Atlantic anticyclones, the north-south seasonal displacement of the Intertropical Convergence Zone, humidity transport from the Amazon, and with the formation of a center of high pressure in high levels of the atmosphere, known as the Bolivian High (Virji, 1981; Silva Dias et al., 1983). The spatial and temporal variability of seasonal precipitation in the Andean region is similar to that observed in the rest of South America (Figueroa and Nobre, 1990). 
Table 1. List of meteorological station.

\begin{tabular}{|c|c|c|c|c|c|c|c|c|c|c|c|c|}
\hline & No. & $\begin{array}{l}\text { Station } \\
\left({ }^{\circ} \mathrm{W}\right)\end{array}$ & $\begin{array}{l}\text { Longitud } \\
\qquad\left({ }^{\circ} \mathrm{S}\right)\end{array}$ & $\begin{array}{l}\text { Latitud } \\
\text { (ma.s.l.) }\end{array}$ & $\begin{array}{l}\text { Altitude } \\
\text { (mm) }\end{array}$ & Annual precip. & No. & $\begin{array}{l}\text { Meteorological Station } \\
\left({ }^{\circ} \mathrm{W}\right)\end{array}$ & $\begin{array}{l}\text { Longitd } \\
\left({ }^{\circ} \mathrm{S}\right)\end{array}$ & $\begin{array}{l}\text { Latitud } \\
\text { (ma.s.l.) }\end{array}$ & $\begin{array}{l}\text { Altitude } \\
\text { (mm) }\end{array}$ & Annual precip. \\
\hline \multirow{5}{*}{ Coast } & 1 & Tumbes & 80.40 & 3.55 & 27 & 466 & 6 & Trujillo & 79.02 & 8.11 & 30 & 5 \\
\hline & 2 & Talara & 81.27 & 4.58 & 90 & 74 & 7 & Chimbote & 78.52 & 9.17 & 11 & 8 \\
\hline & 3 & Piura & 80.63 & 5.20 & 55 & 133 & 8 & Lima & 77.12 & 12.00 & 13 & 14 \\
\hline & 4 & Chiclayo & 79.83 & 6.77 & 34 & 34 & 9 & Pisco & 76.28 & 13.75 & 7 & 2 \\
\hline & 5 & Talla & 79.47 & 7.24 & 20 & 20 & 10 & Tacna & 70.30 & 18.07 & 458 & 26 \\
\hline \multirow{13}{*}{ Highlands } & 11 & Ardilla & 80.43 & 4.52 & 150 & 543 & 24 & Huancavelica & 74.98 & 12.78 & 3680 & 518 \\
\hline & 12 & Frias & 79.90 & 4.83 & 3010 & 1120 & 25 & Ayacucho & 74.22 & 13.13 & 2749 & 527 \\
\hline & 13 & Aranza & 79.98 & 4.85 & 1300 & 459 & 26 & Cusco & 71.98 & 13.55 & 3249 & 737 \\
\hline & 14 & Canchaque & 79.60 & 5.37 & 1200 & 822 & 27 & Crucero & 70.03 & 14.33 & 4400 & 599 \\
\hline & 15 & Cajamarca & 78.47 & 7.13 & 2622 & 545 & 28 & Chuquibambilla & 70.73 & 14.80 & 3970 & 410 \\
\hline & 16 & Huaraz & 77.60 & 9.36 & 2760 & 642 & 29 & Huaraya-Moho & 69.47 & 15.38 & 3890 & 606 \\
\hline & 17 & Huanuco & 75.75 & 9.90 & 1860 & 376 & 30 & Juliaca & 70.15 & 15.48 & 3826 & 583 \\
\hline & 18 & Upamayo & 76.28 & 10.92 & 4080 & 573 & 31 & Lagunillas & 70.65 & 15.77 & 4200 & 658 \\
\hline & 19 & Pachacayo & 75.72 & 11.81 & 3550 & 669 & 32 & Laraqueri & 70.05 & 16.13 & 4100 & 512 \\
\hline & 20 & Yauricocha & 75.91 & 11.96 & 4375 & 814 & 33 & Juli & 69.45 & 16.22 & 3820 & 539 \\
\hline & 21 & Huayao & 75.32 & 12.03 & 3313 & 755 & 34 & Arequipa & 71.55 & 16.32 & 2520 & 94 \\
\hline & 22 & Pampas & 74.87 & 12.39 & 3260 & 542 & 35 & Desaguadero & 69.03 & 16.57 & 3812 & 476 \\
\hline & 23 & Chichicocha & 75.61 & 12.17 & 4500 & 437 & 36 & Mazo Cruz & 69.72 & 16.75 & 4050 & 357 \\
\hline \multirow{4}{*}{ Forest } & 37 & Iquitos & 73.25 & 3.75 & 126 & 2732 & 41 & Juanjui & 76.72 & 7.22 & 363 & 1370 \\
\hline & 38 & Yurimaguas & 76.08 & 5.90 & 184 & 2010 & 42 & Pucallpa & 74.60 & 8.42 & 149 & 1507 \\
\hline & 39 & Chachapoyas & 77.83 & 6.22 & 2435 & 755 & 43 & Tingo_Maria & 75.95 & 9.13 & 665 & 3237 \\
\hline & 40 & Tarapoto & 76.38 & 6.45 & 282 & 1111 & 44 & Puerto Maldonado & 69.20 & 12.63 & 266 & 2159 \\
\hline
\end{tabular}

\section{Interanual variability}

The precipitation indices exhibit large variability from month to month and year to year. For visualization purposes, a smooth time series is obtained by applying a six-month running mean to the time series. Figure 2 shows the results for six representative Andean stations. The time series are dominated by interannual variability, where very humid years and very dry years are taken as those where the precipitation indices exceed plus and minus one standard deviation (horizontal lines). The causes of the interannual variability of precipitation will be discussed elsewhere.

\section{Correlation analysis}

\subsection{Equatorial Pacific SST and precipitation}

Correlation analysis between each of the 44 precipitation indices and the 4 SST anomaly indices, corresponding to the regions Niño 1+2, Niño 3, Niño 3.4, and Niño 4, has been performed for each calendar month in the climatological rainy season of October to March. The output of the analysis is presented both in Table 2 and Figs. 3-5.

Table 2 is simplified by only listing values for stations where the correlation magnitude is $>=0.5$. Shading is employed in the table to draw attention to the strongest relationships. From this table one can identify three Andean subregions with different climatic characteristics. The correlation coefficients between the precipitation indices in the Andean region and the SST anomaly indices for El Niño region $1+2$ are moderately positive (the precipitation tends to
Interannual variability of precipitation in six representative stations
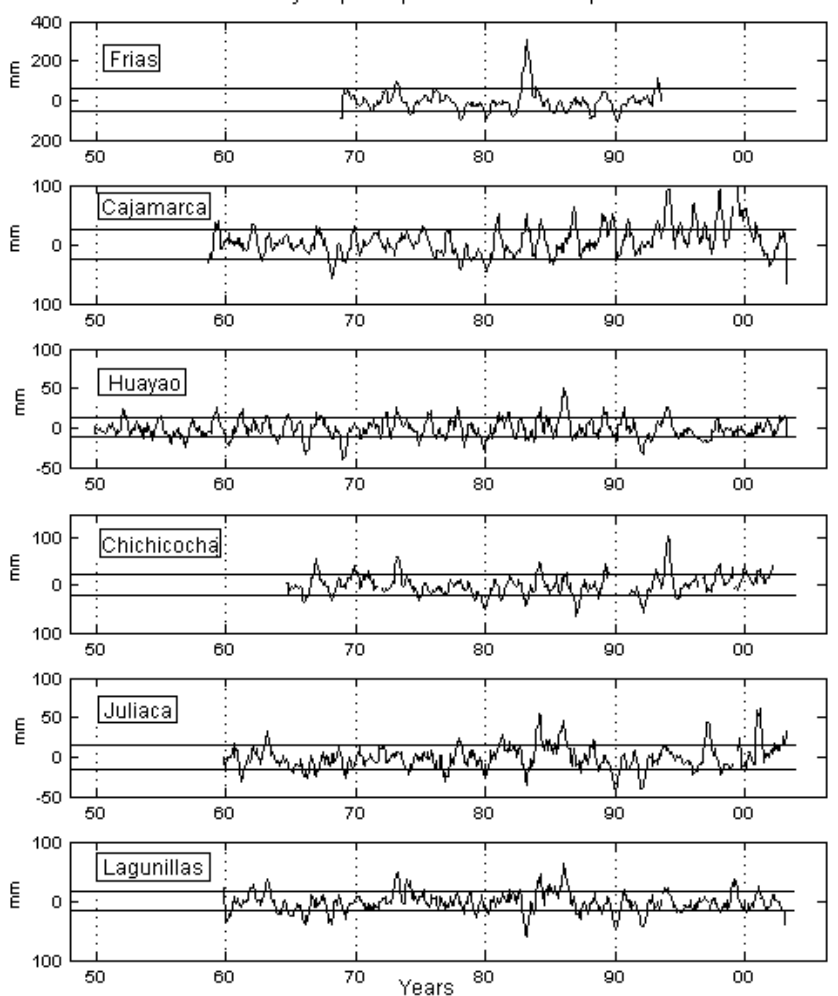

Fig. 2. Six months running mean series for six representative precipitations indices ( $\mathrm{mm} / \mathrm{month})$. 
Table 2. Linear correlation coefficients between SST anomaly indices for El Niño regions and precipitation.

\begin{tabular}{|c|c|c|c|c|c|c|c|c|c|c|c|c|c|c|c|c|c|c|c|c|c|c|c|c|c|}
\hline \multirow{2}{*}{ Station } & \multicolumn{6}{|c|}{ Niño 1+2 } & \multicolumn{6}{|c|}{ Niño 3} & \multicolumn{6}{|c|}{ Niño 3.4} & \multicolumn{6}{|c|}{ Niño 4} & \\
\hline & 0 & $\mathrm{~N}$ & D & $\mathrm{J}$ & $\mathbf{F}$ & M & 0 & $\mathrm{~N}$ & D & $\mathrm{J}$ & $\mathbf{F}$ & M & 0 & $\mathrm{~N}$ & D & $\mathrm{J}$ & $\mathbf{F}$ & M & 0 & $\mathrm{~N}$ & D & $\mathrm{J}$ & $\mathbf{F}$ & M & \\
\hline Tumbes & 0.10 & 0.61 & 0.67 & 0.85 & 0.87 & 0.79 & 0.22 & 0.56 & 0.56 & 0.68 & 0.72 & 0.63 & 0.25 & 0.42 & 0.44 & 0.51 & 0.57 & 0.54 & 0.15 & 0.21 & 0.22 & 0.14 & 0.21 & 0.35 & \\
\hline Talara & -0.05 & 0.47 & 0.54 & 0.73 & 0.73 & 0.67 & -0.14 & 0.41 & 0.42 & 0.60 & 0.67 & 0.69 & -0.16 & 0.32 & 0.33 & 0.45 & 0.55 & 0.51 & -0.16 & 0.18 & 0.17 & 0.21 & 0.28 & 0.26 & \\
\hline Piura & -0.24 & 0.10 & 0.30 & 0.77 & 0.72 & 0.75 & -0.33 & 0.16 & 0.22 & 0.62 & 0.64 & 0.76 & -0.31 & 0.15 & 0.12 & 0.48 & 0.49 & 0.58 & -0.29 & 0.15 & 0.02 & 0.21 & 0.21 & 0.30 & \\
\hline Chiclayo & 0.08 & 0.17 & 0.56 & 0.64 & 0.52 & 0.61 & 0.01 & 0.20 & 0.51 & 0.57 & 0.42 & 0.47 & 0.02 & 0.21 & 0.42 & 0.47 & 0.33 & 0.32 & 0.01 & 0.21 & 0.20 & 0.22 & 0.16 & 0.17 & \\
\hline Talla & -0.09 & 0.27 & 0.71 & 0.48 & 0.66 & 0.56 & -0.17 & 0.40 & 0.60 & 0.31 & 0.54 & 0.47 & -0.19 & 0.39 & 0.49 & 0.18 & 0.40 & 0.33 & -0.21 & 0.34 & 0.30 & -0.01 & 0.15 & 0.14 & \\
\hline Trujillo & 0.20 & 0.59 & 0.54 & 0.20 & 0.58 & 0.48 & 0.24 & 0.57 & 0.43 & 0.20 & 0.41 & 0.46 & 0.25 & 0.48 & 0.33 & 0.17 & 0.31 & 0.28 & 0.16 & 0.34 & 0.19 & 0.11 & 0.18 & 0.13 & \\
\hline Tacna & 0.08 & 0.19 & 0.52 & 0.64 & 0.09 & 0.17 & 0.03 & 0.15 & 0.45 & 0.53 & 0.18 & 0.10 & 0.03 & 0.10 & 0.37 & 0.40 & 0.16 & 0.02 & -0.06 & 0.04 & 0.19 & 0.16 & 0.06 & -0.03 & \\
\hline Ardilla & 0.38 & 0.60 & 0.71 & 0.72 & 0.56 & 0.78 & 0.20 & 0.51 & 0.61 & 0.58 & 0.43 & 0.70 & 0.10 & 0.41 & 0.54 & 0.46 & 0.32 & 0.57 & -0.05 & 0.22 & 0.32 & 0.17 & 0.01 & 0.28 & \\
\hline Frias & -0.03 & 0.40 & 0.65 & 0.67 & 0.31 & 0.53 & -0.16 & 0.26 & 0.46 & 0.48 & 0.18 & 0.31 & -0.17 & 0.16 & 0.32 & 0.36 & 0.01 & 0.18 & -0.19 & 0.03 & 0.10 & 0.12 & -0.21 & 0.08 & \\
\hline Aranza & 0.11 & 0.40 & 0.51 & 0.27 & -0.36 & 0.03 & 0.01 & 0.37 & 0.40 & 0.06 & -0.13 & -0.01 & -0.01 & 0.28 & 0.31 & -0.06 & -0.18 & -0.11 & -0.13 & 0.12 & 0.15 & -0.22 & -0.33 & -0.21 & \\
\hline Canchaque & -0.06 & 0.35 & 0.64 & 0.51 & 0.34 & 0.76 & -0.15 & 0.25 & 0.48 & 0.29 & 0.24 & 0.49 & -0.21 & 0.13 & 0.37 & 0.16 & 0.10 & 0.34 & -0.29 & -0.10 & 0.15 & -0.08 & -0.18 & 0.09 & \\
\hline Yauricocha & -0.12 & -0.04 & 0.25 & -0.10 & -0.27 & -0.02 & -0.21 & -0.08 & 0.15 & -0.22 & -0.41 & -0.14 & -0.25 & -0.10 & 0.05 & -0.25 & -0.53 & -0.21 & -0.21 & -0.09 & -0.09 & -0.25 & -0.57 & -0.28 & Legend: \\
\hline Chuquibambilla & -0.11 & 0.23 & -0.11 & -0.23 & -0.51 & 0.08 & -0.08 & 0.23 & -0.10 & -0.17 & -0.50 & -0.10 & -0.06 & 0.24 & -0.12 & -0.13 & -0.42 & -0.12 & 0.07 & 0.31 & -0.13 & -0.04 & -0.30 & -0.01 & \begin{tabular}{|l|}
$0.5 \mathrm{a} 0.6$ \\
$0.6 \mathrm{a} 0.7$
\end{tabular} \\
\hline Laraqueri & -0.02 & 0.22 & -0.28 & -0.33 & -0.41 & -0.15 & 0.03 & 0.23 & -0.16 & -0.44 & -0.55 & -0.31 & 0.04 & 0.26 & \begin{tabular}{|l}
-0.12 \\
\end{tabular} & -0.46 & -0.58 & -0.36 & 0.12 & 0.34 & -0.12 & -0.35 & -0.52 & -0.25 & $0.7 \mathrm{a} 0.8$ \\
\hline Juli & -0.06 & 0.22 & -0.24 & -0.21 & -0.51 & -0.01 & -0.19 & 0.20 & -0.15 & -0.29 & -0.59 & -0.18 & -0.25 & 0.25 & -0.10 & -0.28 & -0.62 & -0.24 & -0.27 & 0.33 & -0.13 & -0.16 & -0.60 & -0.22 & 0.8 a 0.9 \\
\hline Mazo Cruz & 0.18 & 0.18 & -0.15 & -0.32 & -0.40 & -0.14 & 0.20 & 0.17 & -0.05 & -0.44 & -0.49 & -0.35 & 0.22 & 0.20 & -0.01 & -0.48 & -0.57 & -0.43 & 0.31 & 0.22 & -0.04 & -0.41 & -0.61 & -0.39 & $-0.6 \mathrm{a}-0.0 .7$ \\
\hline
\end{tabular}

\section{Correlation between Precipitation and SST in el Niño 1+2 Region}
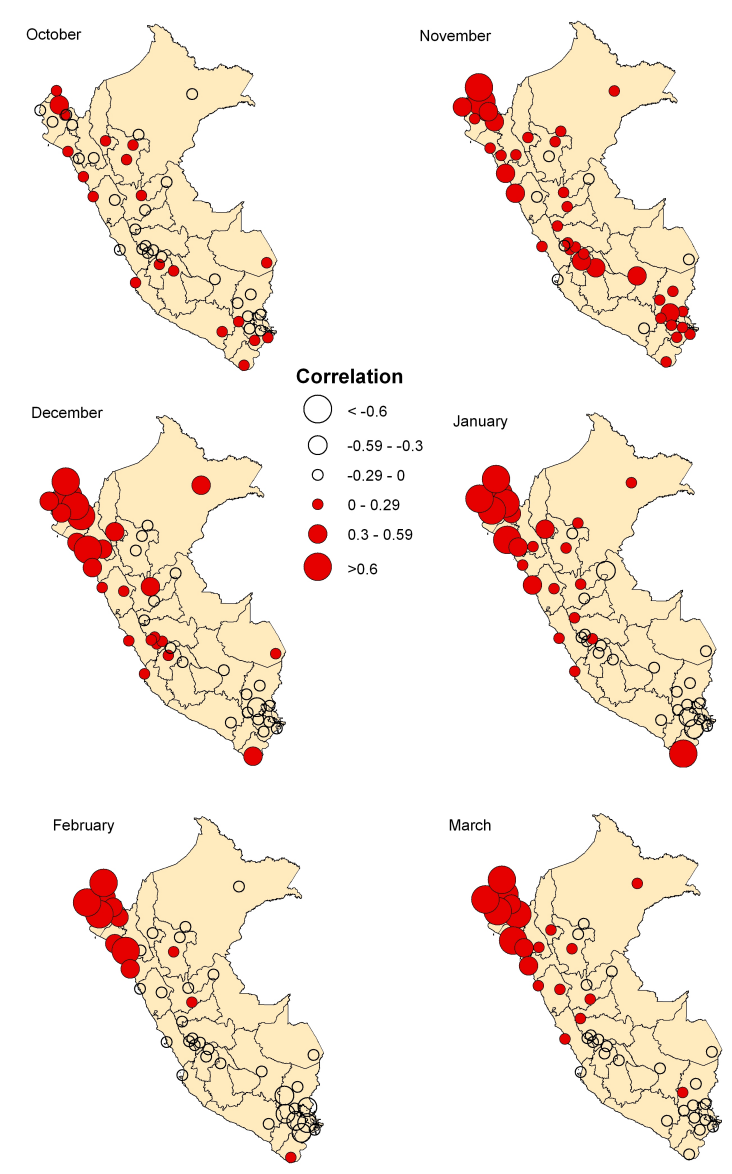

Fig. 3. Correlation between precipitation indices and SST anomaly indices in $\mathrm{El}$ Niño 1+2 region.

\section{Correlation between Precipitation and SST in el Niño 3.4 Region}
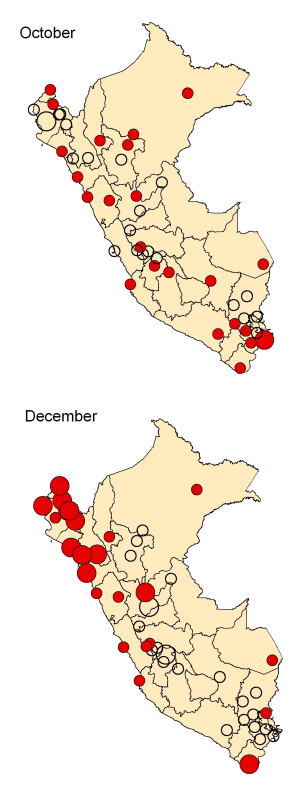

Correlation

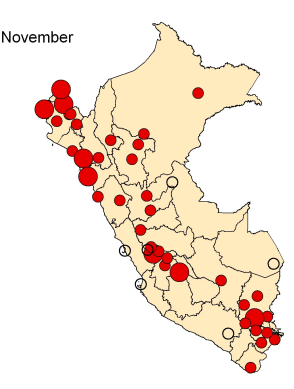

< January

○ $-0.59--0.3$

O $-0.29-0$

$0-0.29$

$0.3-0.59$

$>0.6$
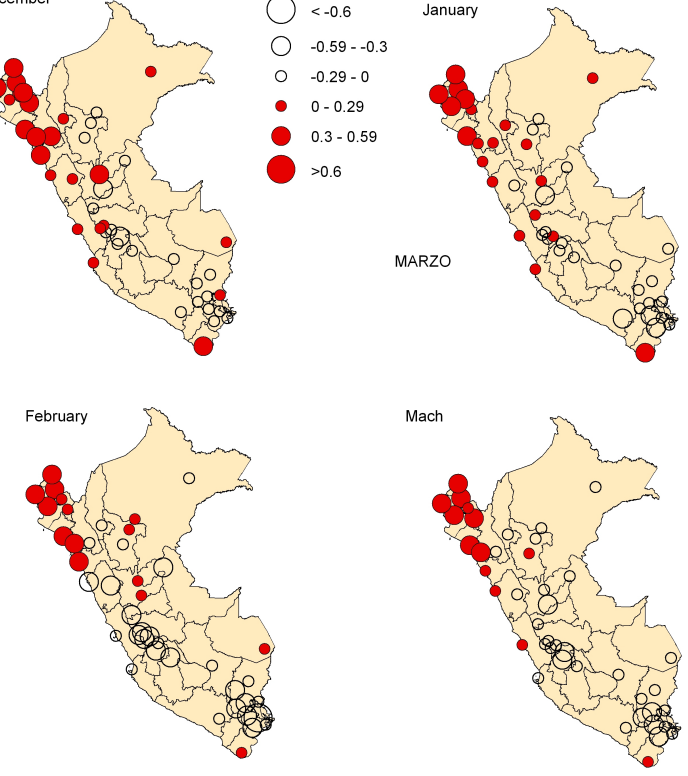

Mach

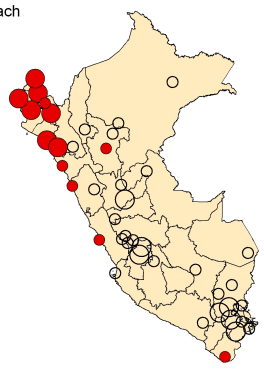

Fig. 4. Correlation between precipitation indices and SST anomaly indices in El Niño 3.4 region. 
be greater than the average during El Niño) in the north end of the northern subregion during November-March. The correlation coefficients are neutral in the central subregion, but moderately positive in November, and are slightly negative (the precipitation tends to be smaller than average during El Niños) in the southern subregion, but moderately negative in February.

The correlation coefficients between the precipitation indices in the Andes and the SST anomaly indices for El Niño region 3.4 are weakly positive in the northern subregion, neutral in the central subregion and moderately negative in the southern subregion, particularly in February. The correlation coefficients between the precipitation indices and the SST anomaly indices for El Niño 4 region are very small in the north and moderately negative in the central and south subregions, particularly in February.

The correlation analysis indicates that precipitation in the northern coast is strongly related to the SST anomaly indices for El Niño region 1+2, mainly in the period January-March. During El Niño events, as defined by SCOR, the relationship intensifies, confirming the results of previous studies (Woodman, 1999, and numerous others). The correlation coefficients between the precipitation indices in the Peruvian Amazon region and the SST anomaly indices for the four El Niño regions are small in magnitude.

Figure 3 depicts the correlation between the precipitation indices and SST anomalies for the El Niño 1+2 region for the calendar months October to March. Figures 4 and 5 show the results of the correlation between precipitation indices and SST anomaly indices for El Niño 3.4 and El Niño 4 regions, respectively. In these figures the magnitudes of the correlation coefficients are indicated by the size of the open and shaded circles. Stronger positive correlations, represented as large shaded circles, are shown in Fig, 3 for the northern coast from November to March. Similarly, in Fig. 4 moderate positive correlations are observed in the northern coast from November to March, and in Fig. 5 moderate positive correlations are observed along the Andean region in November. Moderate negative correlations with both El Niño 3.4 and El Niño 4 are observed along the Andean region in January, February and March (Figs. 4 and 5).

\subsection{Precipitation forecast in Peru}

The forecast of monthly precipitation anomalies in Perú relies on the correlation analysis presented in this paper and on the prediction of SST anomalies in El Niño regions. Most of the international effort in predicting SST anomalies in the equatorial Pacific has been focused in El Niño 3.4 region since large positive and negative SST anomalies in this region has global climatic consequences and relatively little attention has been given to the prediction of SST anomalies, for example, in the El Niño $1+2$ region. This is probably due to the fact that the ability to predict SST anomalies in El Niño 3.4 region is higher than in El Niño 1+2 region, due to
Correlation between Precipitation and SST in el Niño 4 Region
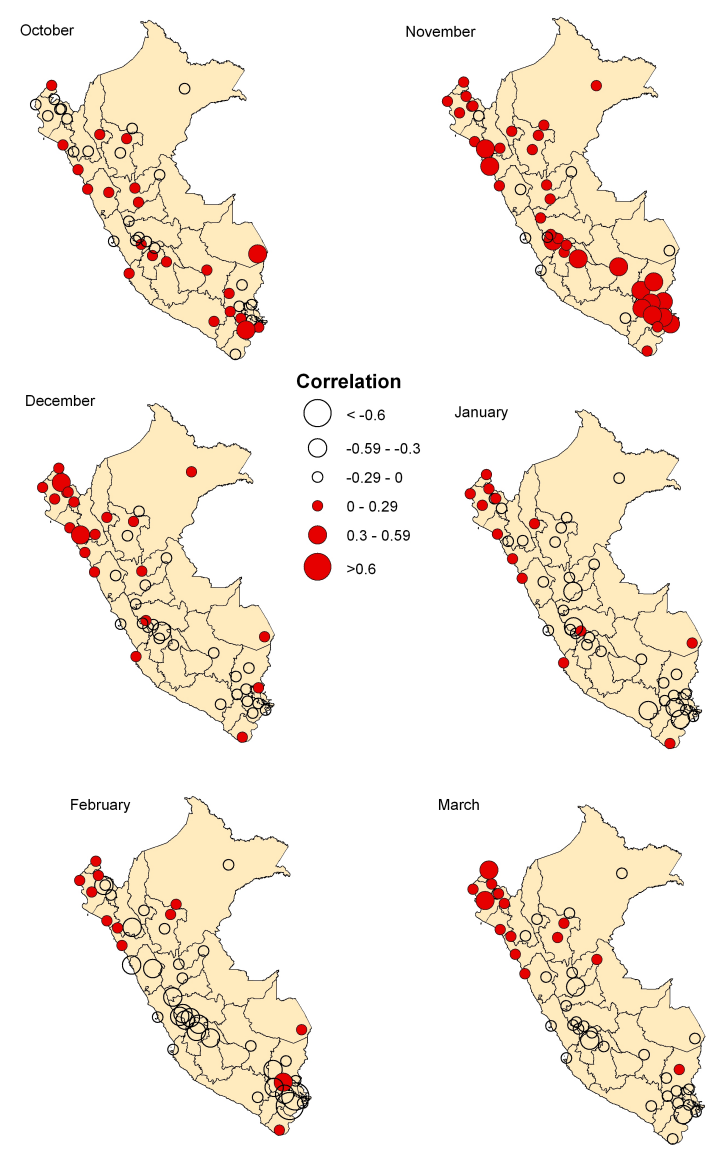

Fig. 5. Correlation between precipitation indices and SST anomaly indices in El Niño 4 region.

a more complex physics processes involved in El Niño $1+2$ region than in El Niño 3.4 region.

SST anomaly forecasts for El Niño 3.4 regions are routinely available from the NOAA Climate Prediction Center and, if we assume that SST anomalies in El Niño 3.4 are representative of SST anomalies over the entire equatorial Pacific, precipitation anomalies can be forecast for Perú. The correlation analysis of Sect. 6.1 documents the greater sensitivity of north coastal precipitation anomalies to local SST anomalies than to basin-scale SST variations, which suggests the usefulness of predicting El Niño 1+2 SST variability. To investigate the extent to which one can use SST anomalies in El Niño 3.4 region to predict SST anomalies in the El Niño $1+2$ region, a linear lag correlation analysis between SST anomaly in El Niño 3.4 and El Niño 1+2 regions has been performed.

Table 3 shows the lagged correlation coefficients between SST anomaly indices in El Niño 3.4 and El Niño 1+2 regions for six calendar months for the years 1950-2006. Each row is the correlation between Niño 3.4 in a specific calendar month and Niño $1+2$ for months preceding, simultaneous to, or fol- 
Table 3. Lagged correlation coefficients between SSTA indices in El Niño 3.4 and El Niño 1+2 regions for six calendar month.

\begin{tabular}{|c|c|c|c|c|c|c|c|}
\hline M & 0.748 & 0.697 & 0.678 & 0.541 & 0.504 & 0.534 & 0.441 \\
\hline $\mathbf{F}$ & 0.763 & 0.778 & 0.740 & 0.653 & 0.504 & 0.463 & 0.468 \\
\hline $\mathbf{J}$ & 0.775 & 0.808 & 0.820 & 0.714 & 0.598 & 0.384 & 0.326 \\
\hline D & 0.676 & 0.779 & 0.822 & 0.822 & 0.750 & 0.572 & 0.286 \\
\hline $\mathrm{N}$ & 0.602 & 0.688 & 0.804 & 0.825 & 0.832 & 0.741 & 0.563 \\
\hline \multirow[t]{2}{*}{0} & 0.531 & 0.613 & 0.697 & 0.812 & 0.836 & 0.841 & 0.741 \\
\hline & -3 & -2 & -1 & 0 & 1 & 2 & 3 \\
\hline
\end{tabular}

lowing that month. The month of largest correlation magnitude in each row is shaded. Positive lags are months where Niño $1+2$ follows Niño 3.4. The results indicate that SST anomalies in the El Niño 3.4 region in October and November could be used to predict December SST anomalies in the El Niño 1+2 region. Table 3 also indicates December SST anomaly predictions for the El Niño 3.4 region could be used to predict December SST anomalies in El Niño 1+2 region. It is also suggestive from Table 3 that the SST anomalies propagates from west to east during October and November and propagates from east to west during January to March. To test the sensitivity of Table 3 to conditions before and after the 1976-1977 climate regime shift (Mantua et al., 1997), we repeated the analysis for the periods 1950-1976 and 19772006, and found no substantial difference from those shown in Table 3. Figure 6 is a scatter plot between November El Niño 3.4 and December El Niño 1+2 SST anomalies. A linear model of the relation between these two indices would underestimate the magnitude of the Niño $1+2$ anomaly in the extreme warm years.

Precipitation forecast in the Andean region based on the prediction of SST anomaly in El Niño 3.4 regions is possible for several locations where the correlation coefficient is moderately large in magnitude. Note that the negative correlation improves, particularly in the southern Andean region, when SST anomaly indices for El Niño 4 region are used (Fig. 5), however the prediction of SST anomalies for the El Niño 4 region has limitation and this topic will be discussed elsewhere.

\section{Conclusions and discussion}

Monthly precipitation data from 44 Peruvian stations and SST anomaly indices for the $4 \mathrm{El}$ Niño regions in the equa-

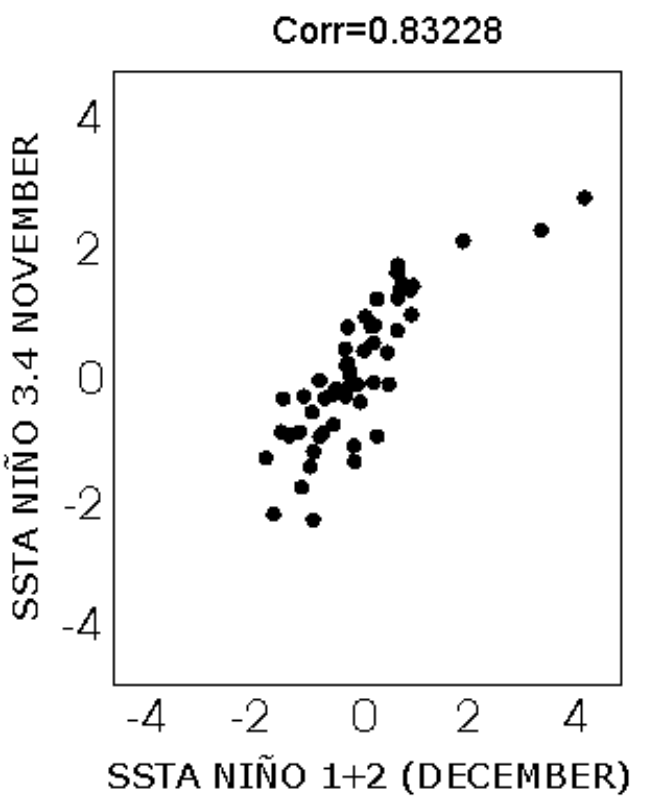

Fig. 6. Scatter plot and correlation coefficient of SSTA indices in El Niño 1+2 (December) and El Niño 3.4 (November) regions.

torial Pacific are used to perform linear correlation analysis with the purpose of establishing the potential for statistical forecasting of monthly precipitation totals in Perú.

The results of the study reveal the following:

- Three subregions with different El Niño precipitation regimes exist in the Andean mountain region, and they are located in the north, center and south of Perú.

- Interannual variability of precipitation is the dominant time scale feature.

- Precipitation extremes in the northern coast of Peru are highly and positively correlated with SST anomalies in El Niño 1+2 region, warm SST forcing precipitation excesses, as several investigators have found.

- Precipitation extremes in the southern Andean region are moderately correlated with SST anomalies in the El Niño 4 region, with positive correlations in November and negative correlations from January to March. The negative correlations, warm SST leading precipitation deficit, is associated with teleconnection mechanism as discussed by Nickl (2007).

- Precipitation forecast in the Andean region based on the prediction of SST anomalies in El Niño 3.4 regions is possible for several locations in Perú where the correlation coefficients are moderately high.

- Considering that precipitation in the northern coast of Perú is only significant from December to March during warm SSTs in the El Niño 1+2 region, precipitation 
forecasts in the northern coast for December are possible using the predicted SST anomaly in the El Niño 3.4 region. For extreme warm events, when the SST anomalies in El Niño 3.4 exceed $1^{\circ} \mathrm{C}$ and in the months when the correlation between both SST anomaly indices is largest, precipitation forecasts for January through March are possible using the predicted SST anomaly in El Niño 3.4 region.

Acknowledgements. The authors thank T. Mitchell for his recommendations and editing the manuscript, the suggestions by an anonymous reviewer helped to improve this manuscript. Many thanks to S. Huaccachi and R. Zubieta for their help with the preparation of the figures.

Edited by: P. Fabian

Reviewed by: M. McPhaden and P. Fabian

\section{References}

Aceituno, P.: On the functioning of the Southern Oscillation in the South America sector. Part I: Surface climate, Mon. Weather Rev., 116, 505-524, 1988.

Aceituno, P.: On the functioning of the Southern Oscillation in the South America sector. Part II: Upper-air circulation, J. Climate, 2, 341-355, 1989.

Barsugli, J. J. and Sardeshmukh, P. D.: Global atmospheric sensitivity to tropical SST anomalies throughout the Indo-Pacific basin, J. Climate, 15, 3427-3442, 2002.

Bjerknes, J.: A possible response of the atmospheric Hadley circulation to equatorial anomalies of ocean temperature, Tellus, 18, 820-829, 1966.

Bjerknes, J.: Atmospheric teleconnections from the equatorial Pacific, Mon. Weather Rev., 97, 163-172, 1969.

Carrillo, C.: Hidrografía oceánica: Las corrientes oceánicas y estudios de la Corriente Peruana ó de Humboldt, Bol. Soc. Geog. Lima, 2, 72-110, 1892.

Climate Prediction Center, NOAA: ftp://ftp.cpc.ncep.noaa.gov/ wd52dg/data/indices/sstoi.indices.

Deser, C. and Wallace, J. M.: El Niño events and their relation to the Southern Oscillation: 1925-86, J. Geophys. Res., 92(C13), 14 189-14 196, 1987.

Díaz, A. E, Studzinski, C. D., and Mechoso, C. R.: Relationships between precipitation anomalies in Uruguay and southern Brazil and sea surface temperature in the Pacific and Atlantic oceans, J. Climate, 11, 251-271, 1998.

Figueroa, S. N. and Nobre, C. A.: Precipitation distribution over central and western tropical south América, Climanálise, 5, 6, 36-45, 1990.

Grimm, A. M., Barros, V. R., and Doyle, M. E.: Climate variability in Southern South America associated with El Niño and La Niña events, J. Climate, 13, 35-58, 2000.

Grimm, A. M., Cavalcanti, I. F. A., and Castro, C. A. C.: Importância relativa das anomalias de temperatura da superficie do mar na produção das anomalias de circulação e precipitação no Brasil num evento El Niño, Anais do XII Congresso Brasileiro de Meteorologia, (en CD), Foz de Iguaçu-PR, Sociedade Brasileira de Meteorologia, 2002.
Liebmann, B. and Marengo, J. A.: Interanual variability of the rainy season and rainfall in the Brazilian Amazon Basin, J. Climate, 14, 4308-4318, 2001.

Mantua, N. J., Hare, S. R., Zhang, Y., Wallace, J. M., and Francis, R. C.: A Pacific interdecadal climate oscillation with impacts on Salmon production, B. Am. Meterol. Soc., 78, 1069-1079, 1997.

Marengo, J. A., Liebmann, B., Kousky, V. E., Filizola, N. P., and Wainer, I. C.: Onset and end of the rainy season in the Brasilian Amazon Basin, J. Climate, 14, 833-852, 2001.

Montecinos, A., Diaz, A., and Aceituno, P.: Seasonal diagnostic and predictability of rainfall in Uruguay, J. Climate, 13, 746758, 2000.

Nickl, E.: Teleconnections and Climate in the Peruvian Andes, MSc. Thesis, Department of Geography, University of Delaware, 2007.

Pisciottano, G., Diaz, A., Gazes, G., and Mechoso, C. R.: ENSouthern Oscillation impact on rainfall in Uruguay, J. Climate, 7, 1286-1302, 1994.

Rasmusson, E. M. and Carpenter, T. H.: Variations in tropical sea surface temperature and surface wind fields associated with the Southern Oscillation/El Niño, Mon. Weather Rev., 110, 5, 354384, 1982.

Reynolds, R. W. and Smith, T. M.: Improved global sea surface temperature analyses using optimum interpolation, J. Climate, 7, 929-948, 1994.

Ropelewski, C. F. and Halpert, M. S.: Global and regional scale precipitation patterns associated with the El Niño/Southern Oscillation, Mon. Weather Rev., 115, 1606-1626, 1987.

Ropelewski, C. F. and Halpert, M. S.: Precipitation patterns associated with the high index phase of the southern oscillation, J. Climate, 2, 268-284, 1989.

Scientific Commitee on Oceanic Research (SCOR) Working Group 55: Prediction of El Niño in SCOR Proceedings, 19, 47-51, 1983.

Silva Dias, P. L., Shubert, L. W., and DeMaria, M.: Large scale response of tropical atmosphere to transient convection, J. Atmos. Sci., 40, 2689-2707, 1983.

Trenberth, K. E.: The definition of El Niño, B. Am. Meterol. Soc., 78, 2771-2777, 1977.

Trenberth, K. E. and Stepaniak, D. P.: Indices of El Niño evolution, J. Climate, 14, 1697-1701, 2001.

Villacís, M. E., Galárraga, S. R., and Francou, B.: Influencia de El Niño-Oscilación del Sur (ENOS) sobre la precipitación en los Andes centrales del Ecuador, III Encuentro de las Aguas, Bolivia, 2001.

http://www.aguabolivia.org/situacionaguaX/IIIEncAguas/ contenido/trabajos_rojo/TC-054.htm

Virji, H.: A preliminary study of summertime Tropospheric circulation patters over South America estimated from cloud wind, Mon. Weather Rev., 109, 599-610, 1981.

Vuille, M. R. B. and Keimig, F.: Climate Variability in the Andes of Ecuador and its relation to tropical Pacific and Atlantic sea surface temperature anomalies, J. Climate, 13, 2520-2535, 2000.

Woodman, R.: Modelo Estadístico para el pronóstico de las precipitaciones en la costa norte, Presentados en el I encuentro de Universidades del Sur (RUPSUR), Piura, available in: http: //www.igp.gob.pe/rupsur.pdf, 1999. 